\title{
THROMBOPHILIC FACTORS IN ISCHAEMIC AND NON-ISCHAEMIC IDIOPATHIC RETINAL VASCULITIS
}

\author{
H. E. PALMER ${ }^{1}$, K. M. JURD ${ }^{2}$, B. J. HUNT ${ }^{2}$, A. G. ZAMAN ${ }^{1}$, M. R. STANFORD ${ }^{1}$, \\ M. D. SANDERS ${ }^{1}$ and E. M. GRAHAM ${ }^{1}$ \\ London
}

\begin{abstract}
SUMMARY
Two common causes of visual loss in idiopathic retinal vasculitis ( $R V)$ are retinal ischaemia and cystoid macular oedema. This study investigated whether thrombophilic factors are more prevalent in patients with ischaemic RV than non-ischaemic RV. Twenty patients with RV (10 ischaemic, 10 non-ischaemic) were prospectively recruited before starting systemic immunosuppression. Twenty-one different haemostatic parameters were tested. Seventeen patients had at least one haemostatic abnormality. Three patients had low Protein S, one had low Protein C. Three patients had positive anticardiolipin antibody titres, 1 had poor fibrinolytic activity, 3 had raised fibrinogen levels. Ten patients had raised lipoprotein (a) levels. Fibrinogen levels were higher in the smokers $(p=0.02)$. Although all von Willebrand's factor levels were within the normal range, they were higher in the ischaemic group $(p=0.008)$, in which smoking was more prevalent. This study has shown a high prevalence of thrombophilic abnormalities in $R V$ patients, and implicates smoking in the aetiology of ischaemic RV.
\end{abstract}

Idiopathic retinal vasculitis (RV) is an inflammatory condition of the retinal vessels which predominantly affects young adults and which can lead to blindness. $\mathrm{RV}$ may be associated with a systemic inflammatory disease, with infection or with neoplasia. Alternatively, it can occur in an isolated form, with disease apparently confined to the eye (idiopathic RV). It may be characterised by increased permeability of the retinal vasculature with extravasation of inflammatory cells, leading to cystoid macular oedema and vitritis. Alternatively, it may present with recurrent ischaemic episodes of the retinal microvasculature,

From: Departments of ${ }^{1}$ Medical Ophthalmology and ${ }^{2} \mathrm{Haem}-$ atology, St Thomas' Hospital, London, UK.

Correspondence to: Miss H. E. Palmer, Department of Ocular Immunology, Rayne Institute, St Thomas' Hospital, London SE1 7EH, UK. resulting in retinal ischaemia and the potential for neovascularisation and vitreous haemorrhage. ${ }^{1}$ Thus, RV can be broadly classified into non-ischaemic (leaky) and ischaemic forms. Ischaemic RV is frequently, but not universally, seen in ocular inflammation associated with Behçet's disease and is occasionally seen in sarcoidosis. ${ }^{1,2}$ It can also be a prominent feature of infective retinal disease such as tuberculosis. In contrast, ocular inflammation associated with multiple sclerosis or seronegative arthritis tends to produce vascular leakage only, with retinal ischaemia being rare. In the case of idiopathic isolated RV, however, either ischaemic or nonischaemic disease may occur and the mechanisms favouring the pathogenesis of either type remain unclear.

According to Virchow's triad, thrombosis occurs when there are abnormalities within the vessel wall, in the constituents of the blood (thrombophilic factors) or in blood flow, either singly or in combination. ${ }^{3}$ We hypothesised that a pre-existing thrombophilia (either genetic or acquired) may be involved in the pathogenesis of idiopathic RV. Examples of these changes are a deficiency of physiological anticoagulants such as Protein C, Protein S or antithrombin III, or an excess of coagulation factors, such as fibrinogen. It has recently been suggested that in Behçet's disease thrombosis occurs only when additional haemostatic abnormalities are present: several patients have been described with congenital Protein S deficiency. ${ }^{4}$

Ischaemic rather than non-ischaemic $\mathrm{RV}$ may arise as a consequence of one or both of the following: firstly, a higher prevalence of pre-existing thrombophilic factors in ischaemic compared with nonischaemic RV patients and, secondly, greater retinal vascular endothelial perturbation in the ischaemic disease, which causes thrombosis. Endothelial damage or perturbation may be detected by 
Table I. Haemostatic parameters tested

\begin{tabular}{|c|c|}
\hline Parameters & Laboratory method \\
\hline $\begin{array}{l}\text { Coagulation factors } \\
\text { Fibrinogen } \\
\text { International normalising ratio (INR) } \\
\text { Activated partial thromboplastin time (APTT) } \\
\text { Factor VII } \\
\text { Factor VIII } \\
\text { von Willebrand's factor (vWF) }\end{array}$ & $\begin{array}{l}\text { Automated on ACL using Instrumentation Laboratory } \\
\text { Reagents (IL) } \\
\text { ELISA (in-house) }\end{array}$ \\
\hline $\begin{array}{l}\text { Physiological anticoagulants } \\
\text { Protein S (free and total) } \\
\text { Protein C } \\
\text { Antithrombin III }\end{array}$ & $\begin{array}{l}\text { ELISA (in-house) } \\
\text { Functional chromogenic substrate assays (Coamate Protein C } \\
\text { and Coatest AT III, Quadratech) }\end{array}$ \\
\hline $\begin{array}{l}\text { Fibrinolysis } \\
\text { Tissue plasminogen activator: antigen } \\
\text { Plasminogen activator inhibitor: antigen } \\
\text { Tissue plasminogen activator: activity } \\
\text { Plasminogen activator inhibitor: activity } \\
\text { Plasminogen } \\
\text { D-dimers } \\
\text { Lipoprotein (a) }\end{array}$ & $\begin{array}{l}\text { ELISA (TintElize tPA and TintElize PAI-1, Biopool) } \\
\text { Functional chromogenic substrate assays (Coaset tPA, Coatest } \\
\text { PAI-1, Quadratech and IL-test plasminogen, IL) } \\
\text { Dimertest II, Agen, Latex agglutination, ELISA (Tint-Elize } \\
\text { Lp(a), Biopool) }\end{array}$ \\
\hline $\begin{array}{l}\text { Antiphospholipid antibodies } \\
\text { Dilute Russell's viper venom time (DRVVT) } \\
\text { Anticardiolipin antibodies }\end{array}$ & $\begin{array}{l}\text { Clotting test (in-house) } \\
\text { ELISA (in-house) }\end{array}$ \\
\hline $\begin{array}{l}\text { Molecular markers of haemostatic activation } \\
\text { Thrombin-antithrombin complexes } \\
\text { Prothrombin fragments } 1+2 \\
\text { Plasmin } \alpha_{2} \text {-antiplasmin complexes }\end{array}$ & $\begin{array}{l}\text { Enzygnost TAT (Behringwerke AG), ELISA } \\
\text { (Thrombonostika F1.2, Organon Teknika) Technoclone PAP } \\
\text { ELISA kit (Immuno) }\end{array}$ \\
\hline
\end{tabular}

increased plasma levels of endothelial products, such as von Willebrand's factor (vWF) and fibrinolysis activators.

It is possible that local thrombosis in the retinal vasculature may be detected by measuring the levels of the recently described haemostatic markers of activation, which reflect 'turnover' of haemostasis. Examples of these are thrombin-antithrombin complexes, prothrombin fragments $1+2$ and plasmin $\alpha_{2}$-antiplasmin complexes.

The aim of this study was to assess whether a preexisting thrombophilia (either genetic or acquired) is associated with RV, and whether thrombophilia or evidence of vascular endothelial perturbation, or both, are more prevalent in ischaemic than nonischaemic $\mathrm{RV}$.

\section{METHODS}

Twenty consecutive patients with idiopathic isolated RV were recruited prospectively from the Medical Eye Unit at St Thomas' Hospital: 10 with ischaemic $\mathrm{RV}$ and 10 with non-ischaemic RV (according to the findings on fluorescein angiography). Each patient underwent a full general medical history (including enquiry regarding diabetes and hypertension), clinical examination (including urinalysis and blood pressure measurement) and routine blood tests (FBC, ESR, U + Es, LFTs, glucose level, VDRL/ TPHA, serum ACE and chest radiograph) to exclude systemic inflammatory disease. In addition, details of smoking habits, medications, bleeding and thrombotic disorders were recorded. All patients underwent a full ophthalmic examination, as well as fluorescein angiography. A patient was defined as having ischaemic RV if he or she showed angiographic evidence of retinal capillary non-perfusion. Patients were excluded from the study if they were already on systemic immunosuppressants, or had been off these for less than 6 months, or if they were on medications that interfere with haemostasis, such as warfarin and aspirin. Uncuffed venous blood samples were taken from all patients, between 0900 hours and 1100 hours, before starting steroid treatment. The blood samples were then assayed for 21 haemostatic parameters (see Table I). The laboratory tests included coagulation, enzyme-linked immunosorbent assay (ELISA), functional chromogenic substrate and latex agglutination assays.

Non-parametric statistical analysis was done using chi-squared and Mann-Whitney $U$-tests.

\section{RESULTS}

\section{Patient Details}

The age range of all the patients was 19-58 years, with a median of 40 years. The patients with

Table II. Sex distribution, median ages and smoking habits in patients with ischaemic and non-ischaemic RV

\begin{tabular}{lcc}
\hline & Ischaemic RV & Non-ischaemic RV \\
\hline No. of patients & 10 & 10 \\
No. of males & 6 & 4 \\
No. of females & 4 & 6 \\
Median age (years) & 45 & $29(p=0.005)$ \\
No. of smokers & & \\
$\quad<10$ cigarettes/day & 3 & 1 \\
$\quad \geqslant 10$ cigarettes/day & 4 & $2(p<0.005)$ \\
Total & 7 & 2 \\
\hline
\end{tabular}


Table III. Haemostatic abnormalities and type of RV in patients with a personal or family history of vaso-occlusive disease

\begin{tabular}{llll}
\hline Patient & History & Haemostatic abnormality & RV type \\
\hline 1 & Patient had CVA 2 years previously & Anticardiolipin AB +ve & Ischaemic \\
2 & Mother on warfarin; aunt died of thrombosis & Protein S $\downarrow$ & Ischaemic \\
3 & Several siblings with ischaemic heart disease & Fibrinogen $\uparrow$ & Ischaemic \\
4 & Sister with bilateral axillary vein thromboses & Protein S $\downarrow$ Anticardiolipin AB +ve & Non-ischaemic \\
& (aged 21 years) & & \\
\hline
\end{tabular}

CVA, cerebrovascular accident.

ischaemic RV were significantly older than those with non-ischaemic RV, with median ages of 45 and 29 years respectively (Mann-Whitney $U$-test, $p=0.005)$. There were 10 men and 10 women, with no difference in prevalence between the sexes of ischaemic and non-ischaemic RV. None of the patients had any clinical evidence of an active systemic inflammatory disease, and no patient had serological evidence of vasculitis. There was a higher prevalence of smoking in the ischaemic RV group (70\% of the patients with ischaemic RV were smokers, compared with only $20 \%$ of those with non-ischaemic RV; chi-squared, $p<0.05$, see Table II), although there was no difference beween the two groups in terms of quantity of cigarettes smoked. None of the patients was diabetic, hypertensive, nor had any haemoglobinopathy.

Four of the 20 patients had a personal or family history of vascular occlusion and thrombosis, 3 of these patients having ischaemic RV. All 4 of these patients had one or more haemostatic abnormality (see Table III).

\section{Prevalence of Thrombophilia in $R V$}

Seventeen of the twenty patients had at least one haemostatic abnormality ( 9 of 10 of the ischaemic patients, 8 of 10 of those with non-ischaemic disease).

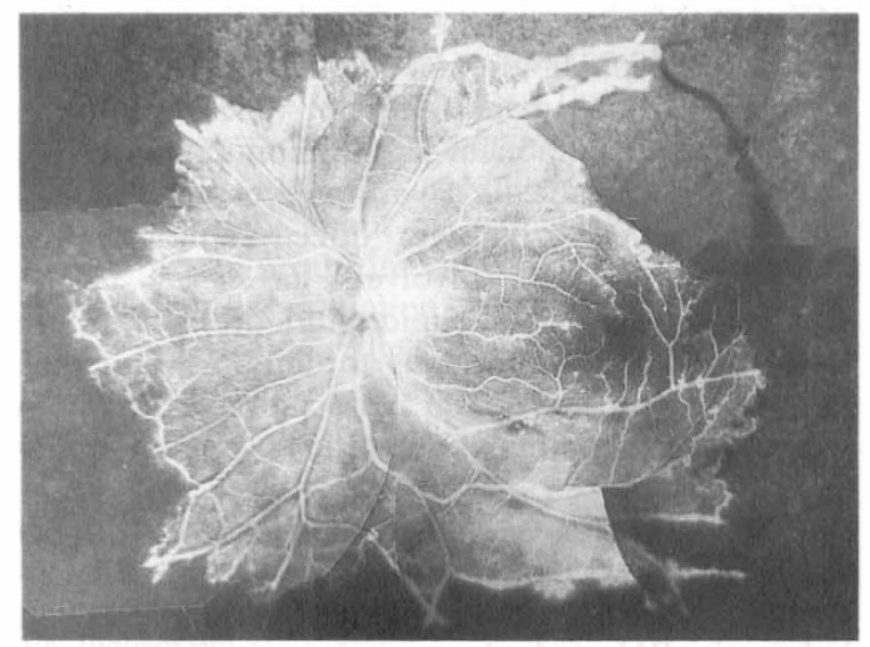

(a)
Three patients had raised fibrinogen levels and 10 patients had lipoprotein (a) (Lp(a)) levels of greater than $300 \mathrm{mg} / \mathrm{l}$. More significantly, however, 1 patient had low Protein $\mathrm{C}$ and 3 had low Protein S levels. One patient with ischaemic RV showed reduced fibrinolytic activity, exemplified by reduced tissue plasminogen activator (tPA) activity, raised plasminogen activator inhibitor (PAI) antigen activity, as well as raised fibrinogen. Three patients had positive anticardiolipin antibody titres, 1 of whom also had a reduced Protein S level.

\section{Comparison of Ischaemic with Non-ischaemic $R V$}

Patients with ischaemic RV had significantly higher levels of von Willebrand's factor (vWF) compared with those with non-ischaemic RV (Mann-Whitney $U$-test, $p=0.008$; see Fig. 2), although none of the patients had levels outside the normal range. There was a similar trend for factor VIII levels (MannWhitney $U$-test, $p=0.059$ ). None of the other haemostatic parameters showed differences between the two patient groups. vWF was also significantly higher in the patients who smoked compared with those who did not $(p=0.004)$, as was the case for fibrinogen levels $(p=0.02)$. Of the 9 patients who were smokers, 4 smoked fewer than 10 cigarettes per day, whilst 5 smoked 10 or more per

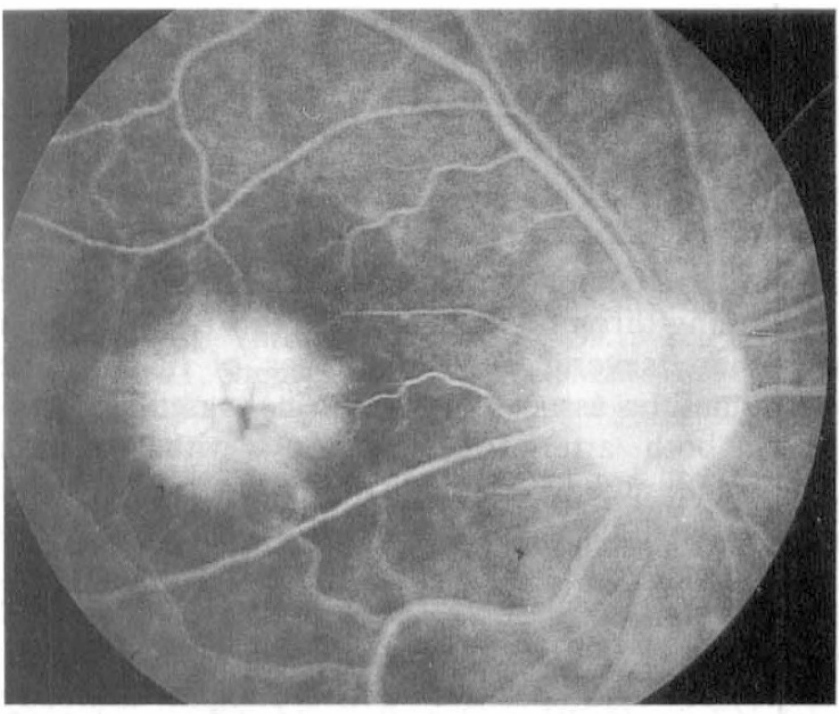

(b)

Fig. 1. Composite fluorescein angiographs of retinal vasculitis patients with (a) extreme peripheral retinal vascular closure and (b) the petalloid hyperfluorescence of cystoid macular oedema. 


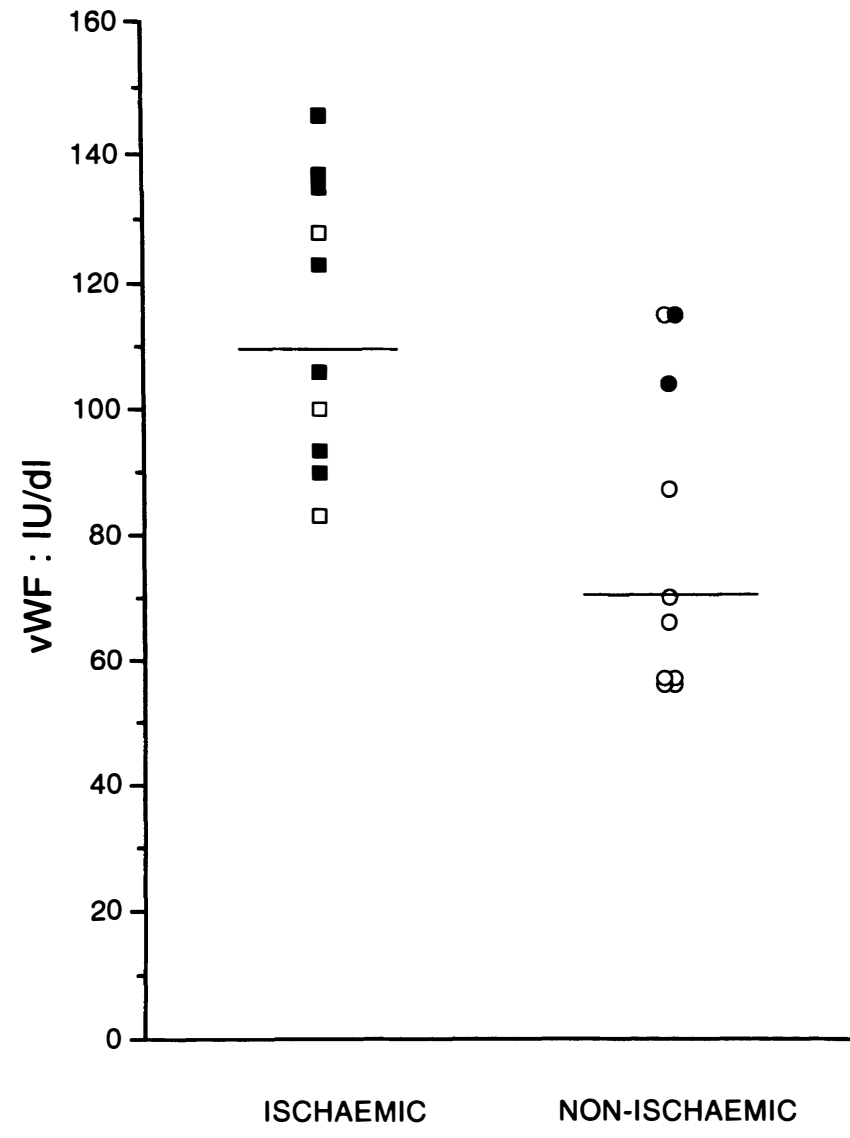

Fig. 2. The levels and medians of von Willebrand's factor antigen $(v W F)$ in patients with ischaemic retinal vasculitis $(R V)$ compared with non-ischaemic $R V$. Filled squares, ischaemic $R V+$ smokers; open squares, ischaemic $R V+$ non-smokers; filled circles, non-ischaemic $R V+$ smokers; open circles, non-ischaemic $R V+$ non-smokers.

day. vWF levels were not significantly higher in this latter group of heavier smokers. There was no significant difference in fibrinogen levels between the ischaemic and non-ischaemic RV patients.

\section{Evidence of Haemostatic Activation}

None of the $20 \mathrm{RV}$ patients had raised haemostatic markers of activation.

\section{DISCUSSION}

There have been no previous reports in the literature examining thrombophilic disorders in RV, although there are several published cases of haemostatic abnormalities associated with retinal vascular occlusions, both arterial and venous, with Behçet's syndrome, and with amaurosis fugax..$^{4-11}$ We have found a high prevalence of pre-existing thrombophilic factors in patients with idiopathic retinal vasculitis.

In this study, 1 of the 20 patients had Protein $C$ deficiency and 3 had Protein $S$ deficiencies, either alone or with positive anticardiolipin antibody titres - a higher prevalence than would be expected in the normal population. Under normal conditions there is a balance between the coagulation cascade, which leads to the formation of fibrin, the physiological anticoagulants which act to prevent the formation of fibrin, and the fibrinolytic pathway which breaks down the fibrin once it has formed. ${ }^{12} \mathrm{~A}$ deficiency in the physiological anticoagulants Protein $\mathrm{C}$ and Protein $\mathrm{S}$ can lead to the tendency for thrombosis. Protein $\mathrm{C}$ exerts its anticoagulant effects by degrading the activated forms of factors $\mathrm{V}$ and VIII, and is itself activated at the vascular endothelial cell surface by a thrombin-thrombomodulin complex. Protein $\mathrm{S}$ acts as a co-factor for activated Protein $\mathrm{C}$ and it exists in the plasma in two forms: free and bound. The $\mathrm{C} 4 \mathrm{~b}$-binding protein binds to $50 \%$ of the total Protein S, leaving $50 \%$ in the free form. ${ }^{13}$ Deficiencies in these two proteins can be inherited in both the homozygous and heterozygous form. The homozygous form presents in the neonatal period with purpura fulminans and skin necrosis, and is frequently fatal. Heterozygous Protein C deficiency usually presents with venous occlusions, superficial thrombophlebitis being the commonest. ${ }^{14}$ The prevalence of heterozygous Protein C deficiency in the general population is a matter of debate, estimates varying from 1 in $300^{15}$ to 1 in $16000 .^{16}$ Heterozygous Protein S deficiency also presents with venous thromboembolism, superficial thrombophlebitis and deep vein thromboses being equally common.

Three of the 20 patients had positive anticardiolipin titres, compared with a $1-2 \%$ prevalence in the general population. The presence of anticardiolipin antibodies in peripheral blood is associated with thrombotic states. Anticardiolipin antibodies are one of a group of antiphospholipid antibodies which are found in patients with primary antiphospholipid syndrome, systemic lupus erythematosus and syphilis. ${ }^{13}$ Antiphospholipid antibodies are a heterogeneous group of antibodies which bind to negatively charged phospholipid components. They may have an in vitro anticoagulant effect by reacting with the phospholipid component of prothombinase in the coagulation cascade. In vivo, however, they have a paradoxical prothrombotic effect, although the precise mechanisms involved have yet to be elucidated. Antiphospholipid antibodies predispose to both arterial and venous thromboses, and they have been described in association with both neurological conditions and retinal vascular occlusions. ${ }^{17-20}$

Half the patients studied demonstrated $L p(a)$ levels $>300 \mathrm{mg} / \mathrm{l}$, either in isolation or in combination with another thrombophilic abnormality (4 had ischaemic RV, 6 had non-ischaemic RV). Lp(a) inhibits fibrinolysis by impairing tPA activity, by interfering with plasminogen binding and activation on fibrin, and by augmenting PAI-1 activity. ${ }^{21}$ Levels of $\mathrm{Lp}(\mathrm{a})$ above $300 \mathrm{mg} / \mathrm{l}$ are reported to double the 
risk of coronary heart disease, ${ }^{22}$ but high levels have not previously been measured in association with ocular disease. This does, however, have implications in the long term for the general health of $\mathrm{RV}$ patients.

Only 1 of 21 tests, namely that for vWF, showed a significant difference between ischaemic and nonischaemic RV, and factor VIII levels showed a similar trend. vWF is a large glycoprotein which is synthesised in the vascular endothelium, and high levels reflect endothelial cell perturbation or damage. ${ }^{23}$ Although vWF levels were significantly higher in the ischaemic RV group, all levels for both the ischaemic and non-ischaemic RV patients were within the normal range. For this reason, vWF appears to be a poor discriminator between ischaemic and non-ischaemic RV. Smoking can raise vWF levels because of the endothelial damage caused by products of tobacco combustion. ${ }^{24}$ There was a higher prevalence of smoking in the ischaemic RV group, who had higher vWF levels: 7 of the 9 smokers had ischaemic RV, and vWF levels were significantly higher in the RV patients who smoked compared with those who did not. Since factor VIII is carried by $\mathrm{vWF}$, it is not surprising that the former showed a similar trend in the two groups. Fibrinogen levels were significantly higher in smokers, which is a well-recognised association, and possibly a mechanism by which smoking causes atherosclerotic disease and increased venous thrombotic events.

\section{CONCLUSION}

This study has shown a high prevalence of thrombophilic abnormalities in patients with idiopathic retinal vasculitis, and argues for these patients to undergo thrombophilia screening. von Willebrand's factor (vWF) was the only haemostatic parameter which differentiated ischaemic from non-ischaemic RV, despite all the levels being within the normal range. The higher vWF levels seen in the ischaemic RV patients may be the consequence of smoking, or alternatively, may be secondary to endothelial damage brought about by retinal vascular closure. In view of the prothrombotic effect of smoking, and the probable association between prothrombotic states and RV, we suggest that patients with this sight-threatening disease should be advised not to smoke.

This study was supported by the T.F.C. Frost Charitable Trust and the Iris Fund for Prevention of Blindness. We would like to thank Mr Richard Dewhirst for providing the fluorescein photographs and Mrs Dora Paterson for typing the manuscript.

Key words: Retinal vasculitis, Thrombosis.

\section{REFERENCES}

1. Sanders MD. Duke Elder Lecture. Retinal arteritis, retinal vasculitis and autoimmune retinal vasculitis. Eye 1987;1:441-65.

2. Graham EM, Stanford MR, Sanders MD, Kasp E, Dumonde DC. A point prevalence study of 150 patients with idiopathic retinal vasculitis. I. Diagnostic value of ophthalmological features. Br J Ophthalmol 1989;73:714-21.

3. Lindop GDM, Percy-Robb IW, Walker ID. Disturbances of body fluids, haemostasis and the flow of blood. In: MacSween RNM, Whaley K, editors. Muir's textbook of pathology. 13th ed. London: Edward Arnold, 1992:92-3.

4. Chafa O, Fischer AM, Meriane F, Chellali T, Sternberg C, Otmani F, Benabadji M. Behçet syndrome associated with Protein S deficiency. Thromb Haemost 1992;67:1-3.

5. Pivetti-Pezzi P, Priori R, Caterinelli G, Meroni PL, Federici A.B, Abdulaziz M, et al. Markers of vascular injury in Behçet's disease associated with retinal vasculitis. Ann Ophthalmol 1992;24:411-4.

6. Nelson ME, Talbot JF, Preston FE. Recurrent multiple-branch retinal arteriolar occlusions in a patient with Protein C deficiency. Graefes Arch Clin Exp Ophthalmol 1989;227:443-7.

7. Ririe DG, Cosgriff TM, Martin B. Central retinal vein occlusion in a patient with familial antithrombin III deficiency: case report. Ann Ophthalmol 1979;11: $1841-5$.

8. Golub BM, Sibony PA, Coller BS. Protein S deficiency associated with central retinal artery occlusion. Arch Ophthalmol 1990;108:918.

9. Favilla I, Stubbs K, Kowal L. Abnormal fibrinolysis in retinal vein occlusion. Am J Ophthalmol 1981;9:213-8.

10. Greven CM, Weaver RG, Owen J, Slusher MM Protein S deficiency and bilateral branch retinal artery occlusion. Ophthalmology 1990;98:33-4.

11. Smith DB. Protein C deficiency: a cause of amaurosis fugax? J Neurol Neurosurg Psychiatry 1987;50:361-2.

12. Vine AK, Samama MM. The role of abnormalities in the anticoagulant and fibrinolytic systems in retinal vascular occlusions. Surv Ophthalmol 1993;37:283-92.

13. British Committee for Standards in Haematology. Guidelines on the investigation and management of thrombophilia. J Clin Pathol 1990;43:703-9.

14. Greaves M, Preston FE. Clinical and laboratory aspects of thrombophilia. In: Poller L, editor. Recent advances in blood coagulation, vol. 5. Edinburgh: Churchill Livingstone, 1990:119-40.

15. Miletich J, Sherman L, Broze G. Absence of thrombosis in subjects with heterozygous Protein C deficiency. N Engl J Med 1987;317:991-6.

16. Gladson CL, Sharrer I, Hach V, Beck KH, Griffin JH. The frequency of type I heterozygous Protein C deficiency in 141 unrelated young patients with venous thrombosis. Thromb Haemost 1988;59:18-22.

17. Watts MT, Greaves M, Clearin LG, Malia RG, Cooper SM. Antiphospholipid antibodies and ischaemic optic neuropathy. Lancet 1990;335:613-4.

18. Kleiner RC, Najarian LV, Schatten S, Jabs DA, Patz A, Kaplan HJ. Vaso-occlusive retinopathy associated with antiphospholipid antibodies (lupus anticoagulant retinopathy). Ophthalmology 1989;96:896-904.

19. Acheson JF, Gregson RC, Merry P, Schulenberg WE. Vaso-occlusive retinopathy in the primary antiphospholipid antibody syndrome. Eye 1991;5:48-55.

20. Asherson RA, Merry P, Acheson JF, Harris EN, Jabs DA, Hughes GRV. Antiphospholipid antibodies: a risk factor for occlusive ocular vascular disease. Ann Rheum Dis 1989;48:358-61. 
21. Rabbani LE, Loscalzo J. Recent observation on the role of hemostatic determinants in the development of the atherothrombotic plaque. Atherosclerosis 1994; 105:1-7.

22. Kostner GM, Avogaro P, Cozzolato G, et al. Lipoprotein a and the risk of myocardial infarction. Atherosclerosis 1981;38:51-61.
23. Ruggin ZM. von Willebrand factor and fibrinogen. Curr Opin Cell Biol 19393;5:989-96.

24. Blann AD, McCollum CN. Adverse influence of cigarette smoking on the endothelium. Thromb Haemost 1993;70:707-11.

25. Ernst E. Fibrinogen: an independent risk factor for cardiovascular disease. BMJ 1991;303:596-7. 